\title{
AUTHENTIC ASSESSMENT IMPLEMENTATION IN ENGLISH LEARNING TOWARDS THE ELEVENTH GRADE STUDENTS OF SMA NEGERI 1 TABANAN
}

\author{
Gusti Ayu Gede Sukraningsih \\ Jurusan Pendidikan Bahasa Inggris, Fakultas Pendidikan Bahasa danSeni \\ IKIP Saraswati, Tabanan \\ E-mail: gsukraningsih@gmail.com
}

\begin{abstract}
The achievement of education through learning process is not able tobe separated with learning assessment. In accordance with this, Kemendikbud issues Permendikbud No. 23 Year 2016 governing the standard of assessment, one of which is the utilization of authentic assessment. This research purposed to describe authentic assessment implementation in English learning to the eleventh grade students at SMA Negeri 1 Tabanan. The subjects of this research were an English teacher and 67 students. The techniques utilized to collect the data were observation, interview, and documentation. The data obtained were analysed by using qualitative data analysis. The result of this research showed that: (1) Authentic assessment was implemented in lesson plan and (2) The authentic assessment was implemented meaningfully and integrated in learning process. The assessment's techniques used to assess each competency consist of:(a)observation for attitude competency, (b) most of the assignment for knowledge competency, and (c) performance, project, and portfolio for skills competency. The conclusion of this research is the authentic assessment in English teachingboth in the lesson plan and the learning process is well implemented. It is indicated by the positive opinion stated by the teacher and students towards the implementation of authentic assessment in the process of learning.
\end{abstract}

Key words: authentic assessment, implementation, competency

\section{ABSTRAK}

Pencapaian pendidikan melalui proses pembelajaran tidak dapat dipisahkan dengan penilaian pembelajaran. Sesuai dengan ini, Kemendikbud menerbitkan Permendikbud No. 23 Tahun 2016 yang mengatur tentang standard penilaian, di manasalah satunya adalah penerapan penilaian autentik dalam pembelajaran. Penelitian ini bertujuan untuk mendeskripsikan penerapan penilaian otentik dalam pembelajaran Bahasa Inggris kepada siswa kelas XI SMA Negeri 1 Tabanan. Subyek penelitian ini adalah seorang guru bahasa Inggris dan 67 siswa. Teknik yang digunakan untuk mengumpulkan data adalah observasi, wawancara, dan dokumentasi. Data yang diperoleh dianalisis dengan menggunakan analisis data kualitatif. Hasil penelitian ini menunjukkan bahwa: (1) penilaian autentik dilaksanakan dalam rencana pelaksanaan pembelajaran; (2) Penilaian otentik dilaksanakan dengan baik dalam proses pembelajaran secara bermakna dan terintegrasi. Teknik penilaian digunakan untuk menilai setiap kompetensi terdiri dari: (a) observasi untuk kompetensi sikap, (b) sebagian besar penugasan untuk kompetensi pengetahuan, dan (c) kinerja, proyek, and portofolio untuk kompetensi keterampilan. Kesimpulan dari penelitian ini adalah penilaian otentik dalam pengajaran bahasa Inggris baik dalam rencana pelaksanaan pelajaran serta proses pembelajaran terimplementasi dengan baik. Hal ini ditunjukkan oleh pendapat positif yang 
dinyatakan oleh guru dan para siswa terhadap penerapan penilaian otentik dalam proses pembelajaran.

Kata kunci: penilaianotentik, implementasi, kompetensi

\section{INTRODUCTION}

The development of education purposes to create human resources with integrate competency. In line with this, the government through Kemendikbud runs Permendikbud No. 23 Year 2016 which regulates the standard of assessment. It is stated that learning is the process the interaction process among students, among students and educators and learning sources in learning environment. Meanwhile, the assessment is defined as collection and processing of information to measure students' learning achievement.

The implementation of learning can not be separated with learning assessment. Curriculum 2013 requires the utilization of authentic assessment (Permendikbud 23 Year 2016). It is caused by authentic assessment needs the existence of authentic instruction and authentic learning which are believedto be able to give holistic and valid information towards students' competency. In the implementation of authentic assessment, students are required to show attitude and utilize knowledge and skills which are gained from learning in real situations. Authentic assessment should reflect the real-world problems. In this case, authentic assessment is purposed to measure what is known by the learners and what can be carried out by them.

SMA Negeri 1 Tabanan is a favorite school in Tabanan regency. This school runs the government project through department of education and culture which suggest the schools to run full day school.It means that the learning process is carried out more actively, creatively, and intensively. Full day school is developed to enhance creativity including the competence of attitude, knowledge, and skills.In relation to learning process, the lesson in this school lasts from 07:30 A.M. until 03:40 P.M in which one lesson hour is allocated for 45 minutes. In addition, discipline, keeping environment clean, utilizing bilingual, learning community, learning achievement, and willingness are developedin this school.

Viewing from the learning process in increasing learning progress in this school, the role of assessment is not able to be separated. One of the assessment used in curriculum developed by the government is authentic assessment. Authentic assessment assesses the competence of attitude, knowledge, and skills through the process of learning.

According to Muller (in Nurgiyantoro 2008) authentic assessment is defined as a form of assessment in which students are asked to perform real-world task that demonstrate meaningful application of essential knowledge and skills.Authentic assessment has characteristics consisting of:(a) competency based, (b) individual, (c) student centered, (d) unstructured and open ended, (e) contextual, (f) integrated in the learning process, and (g) on going (Marhaeni, 2010). Meanwhile, Hibbart (in Hosnan, 2014) states that authentic assessment is the assessment which has 
various types of assessment including: (a) performance assessment, (b) observation and questions, (c) presentation and discussion, (d) project and investigation, and (e) portfolio and journal.

In Curriculum 2013, the application of authentic assessment is applied to assess the progress of learners that includes the competency of attitudes, knowledge, and skills (Permendikbud No.23 Year 2016).Based on Permendikbud No. 23 Year 2016, attitudes, skills, and knowledge are assessed by various kinds of techniques. The assessment's techniques for each competency include: (a) attitude competency assessed by observation and other relevant techniques of assessment that the report will be the responsibility of the homeroom teacher; (b) knowledge competency assessment done by written test, oral test, and assignment in accordance with the assessed competency; and skills competency assessment carried out by utilizing the assessment of performance,project, products, portfolio, and/ or other techniques in accordance with the assessed competency.

In line with authentic assessment implementation of attitude competency in learning process, the values of character education are utilized as the basis. According toKemendiknas (2011), the values of character education consist of religious, honesty, tolerance, discipline, working hard, creative, independent, democratic, curiosity, the spirit of nationality, loving country, rewarding achievement, communicative, loving piece, having good reading habit, environmental care, social care, and responsibility.

\section{RESEARCH METHOD}

The research method used in this research was descriptive qualitative. It was used to obtain the comprehensive data occured in line with the authentic assessment implementation towards English learning of the eleventh grade students. The subjects of the research were 67students and an English teacher who taught in the eleventh grade of SMA Negeri 1 Tabanan. The techniques utilized to collect the data were observation, interview, and documentation. The instruments of this research were the researcher as the main instrument, observation sheet, interview guidelines, recording devices, and camera. The qualitative descriptive analysis were used to analyse the data consisting of data collection, data reduction, data display, conclusion, and verification. The matrix of data collection of this research can be seen in the following table:

Table 1: Matrix of Data Collection

\begin{tabular}{|l|l|l|l|}
\hline No & Data & Instruments & $\begin{array}{l}\text { Respond- } \\
\text { ent }\end{array}$ \\
\hline 1 & $\begin{array}{l}\text { Authentic } \\
\text { assessment's } \\
\text { implementation in } \\
\text { the lesson plan }\end{array}$ & $\begin{array}{l}\text { Observation } \\
\text { sheet, } \\
\text { interview, and } \\
\text { documentation }\end{array}$ & Teacher \\
\hline 2 & $\begin{array}{l}\text { Implementation of } \\
\text { authenticassessment } \\
\text { towards students' } \\
\text { activities. }\end{array}$ & $\begin{array}{l}\text { Observation } \\
\text { sheet, } \\
\text { interview, and } \\
\text { documentation }\end{array}$ & $\begin{array}{l}\text { Teacher } \\
\text { and } \\
\text { Students }\end{array}$ \\
\hline
\end{tabular}

\section{RESULT AND DISCUSSION}

The Authentic Assessment Planned in the

\section{Lesson Plan}

Based on the observation and interview to the teacher, authentic assessment was implemented in the lesson plan. It was proven by noticing the arrangement of lesson plan started from core competence including the value of religious, attitude, 
knowledge, and skills. The basic competences, learning objectives, and indicators contained the competencies of attitude, knowledge and skills.

Learning stagesas the core of learning process and learning assessment indicated the relation between learning model and learning approach. Learning models used were discovery learning and project based learning in which scientific approach were inserted in the syntax of learning models. The values of character for assessed were noted in pre- activity, main activity, and post activity. Based on the teacher's interview, the process of assessment lasted in learning stages in which the teacher observed the attitude, knowledge, and skills of the students.

Authentic

assessment processimplementedin learning stages whereasassessmentof learning outcome was the techniques of competency assessment.The assessment of attitude was obtained by using observation sheet containing the character values determined in learning stages. The assignments were mostly used by the teacher to measure knowledge competency in which the students were demanded to do the assignments in groups or individually by utilizing some sources such as internet, books, etc. Meanwhile, skills competency was assessed by performance, project, and portfolio. One of the example of authentic assessment arranged by the teacher in the learning stages and learning outcome assessment of the lesson plan can be seen in the following pictures:

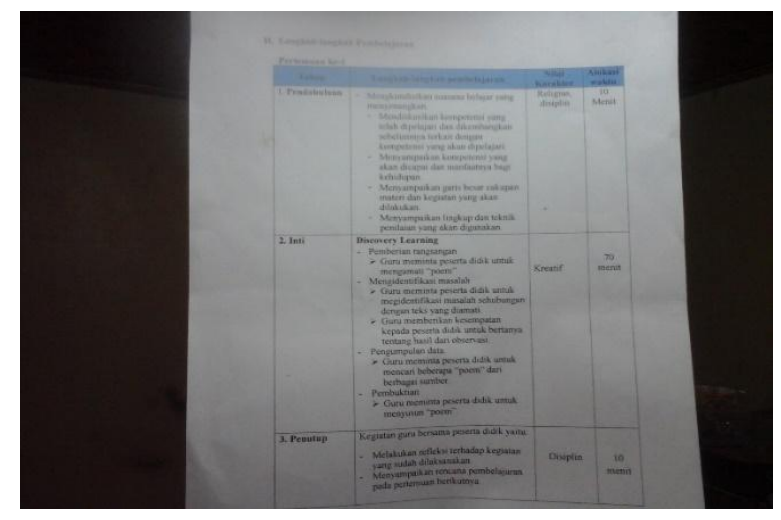

Picture 1: Authentic Assessment in the Lesson Plan Arranged by the Teacher for the first meeting

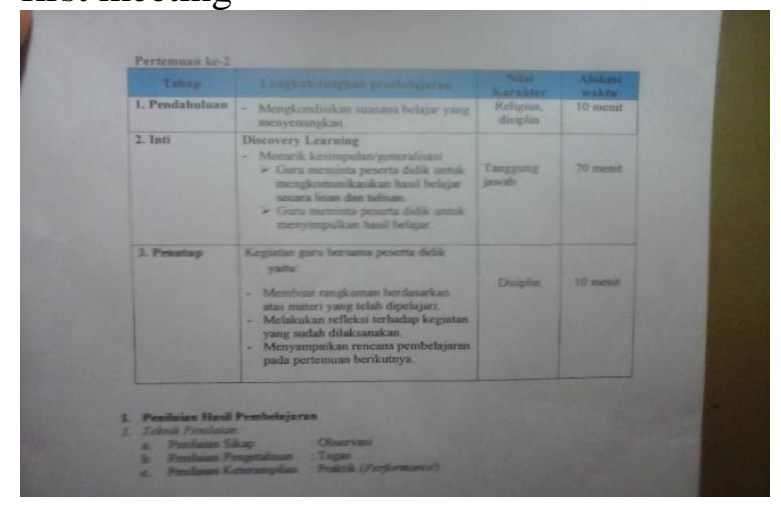

Picture 2: Authentic Assessment in the Lesson Plan Arranged by the Teacher for the Second Meeting

\section{The Implementation of Authentic Assessment in Learning Process}

Authentic assessment consisting of the assessment of attitude, knowledge, and skills were carried out focused on the learning process. In the attitude competency, the teacher valued the students' character based on the values of character including religious, honesty, tolerance, discipline, working hard, creative, independent, democratic, curiosity, the spirit of nationality, loving country, rewarding achievement, communicative, loving piece, having good reading habit, environmental care, social care, and responsibility.The students were mostly given assignment for 
knowledge competence's measurement. The assignments given by the teacher were done mostly in group and sometimes individually.

One of the example of the individual assignment was the activity to create a poem. The students were given the task to make the poem with free of theme. Based on the observation and interview to the students, the poem was made by finding out the information through internet, books, and friends. The students were encouraged and given the opportunities to ask the difficult things in creating poem.

In presenting the student's task, the students' name was not called one by one by the teacher but the chance was given to the brave students. The themes of poem presented by the students were school activities, almighty God, friendship,my inspiration, my inspiration star, beloved parents, best friend, and my love. Most of the poems were presented naturally in language and movement's style. The language used by most of the students were simple and natural. Based on the interview to the students, the poems were made in accordance with the capability and the examples and explanations obtained through internet as the inspiration. The students' activity in presenting poem can be seen in the following picture:

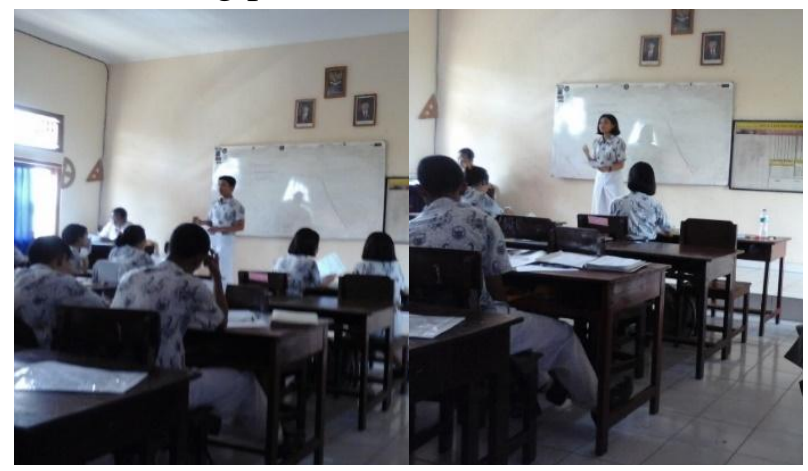

Picture 3: Students' Activities in Presenting
Poem

Meanwhile, the students presented poems with lack of capability were asked by the teacher in relation to the themes, the words used, and the language style. The students were asked wisely weather the poems were just taken from internet. They were asked to make the poems by utilizing some sources to support the ideas and language. This way was carried out by the teacher to practice the students to do the task more creatively and actively.

The assessments including the assessment of attitude, knowledge and skills were obtained through the process of learning. The teacher provided assessment and comments on students learning outcomes. The teacher utilized observation sheet with some character value as the measurements in valuing attitude competency.Knowledge competency was assessedby focusing on the theme, tone, rhyme, diction, and figurative language. Meanwhile, the skill competency was valued through the performance in presenting poem by providing rubrics with several criteria. The rubric used to assess the students' skills in creating and performing poemcan be seen as follows:

Table 2: The Rubric of Skills Competency

\begin{tabular}{|c|c|c|c|c|}
\hline \multirow{2}{*}{$\begin{array}{l}\text { No } \\
1\end{array}$} & Name & Content & Pronunciation & Expression \\
\hline & & & & \\
\hline 2 & & & & \\
\hline 3 & & & & \\
\hline Etc & & & & \\
\hline
\end{tabular}

In addition, the teacher asked the students to do the task in group. The students were demanded to create a short story in the theme of life, friendship, and love. The duty of students was as the writer, designer, and corrector. The task was created by observing 
various kinds of short stories through internet as the example. The difficulties were discussed together to get the solution.The information obtained were collected and analysed in group. The short stories were created by discussing the information which have been analysed. The students started to determine the theme, characters, setting, and plot of the story by imagining the community condition when the story happened. In addition, the students were also asked to determine the moral value containing in the story.

The role of the teacher observed in this activity was as guidance and motivator. The teacher guided the students by understanding students' uniqueness and providing opportunities for the students to consult the learning difficulties. The teacher motivated and the students by encouraging, comprehending students' capability, creating meaningful learning and pleasant learning environment, and providing assessment through students learning. The activities of students and teacher's activities in guiding and motivating the students can be shown in the following picture:

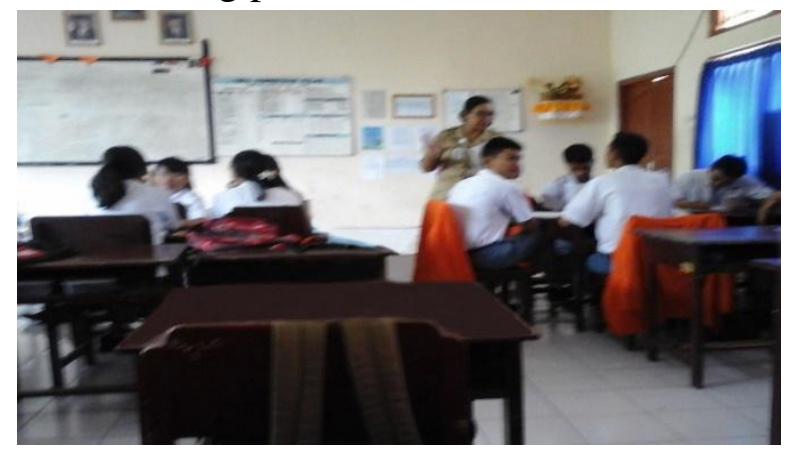

Picture 4: The Students Activities in Creating Short Story Guided and Motivated by the Teacher

The teacher assessed attitude competency by observing the students' activities. In relation to knowledge competency, the students were asked to write down the intrinsic elements includingtheme, characters, plot, setting, and point of view and extrinsic elements consisting of the background of social community and moral values. Whereas, the aspects assessed in skills competency werecoherence, cohesive, diction, grammar, and design.

The students argued that authentic assessment is interesting, challenging, and motivating in which the students are able to share each other, reduce anxiety, create positive attitude to the lesson, and show their own competency. Meanwhile, the teacher states that authentic assessment can enhance students' motivation and creativity in learning process.

\section{CONCLUSION AND SUGGESTION}

Based on the result of this research, it can be concluded that authentic assessment which includes the competency of attitude, knowledge, and skills were implemented in the lesson plan and the learning process.The assessment of attitude was obtained by observation.The assignments were mostly used by the teacher to measure knowledge competency in which the students were demanded to do the assignments in groups or individually. Skills competency was assessed by performance, project, and portfolio. Meanwhile, the role of the teacher in learning process was as guidance and motivator.

The teacher and the students stated positive opinion towards the implementation of authentic assessment in learning process. The students argued that authentic assessment is interesting, challenging, and 
motivating.Meanwhile, the teacher states that authentic assessment can enhance students' motivation and creativity in learning process.

Viewing to the conclusion, it is expected that authentic assessment is very well applied in the learning process because it assesses competency of attitudes, knowledge, and skillsmeaningfully and integrated.

\section{REFERENCES:}

Hosnan, M. (2014). Pendekatan Saintifik dan Kontektual dalam Pembelajaran Abad 21. Bogor: Ghalia Indonesia.

Marhaeni, A.A.I.N. (2010). Pembelajaran Bahasa yang Bermakna. Orasi Ilmiah Pengenalan Guru Besar Tetap. UniversitasPendidikanGanesha.

Nurgiantoro, Burhan. (2008). Pengembangan Model "Authentic Assessment”. Journal.uny.ac.id.

Peraturan Mentri Pendidikan dan Kebudayaan Nomor 23 tahun 2016. Standar Penilaian kurikulum 2013.

Kemendiknas . (2011). Pendidikan Karakter . Jakarta: Kementrian Pendidikan Nasional. 